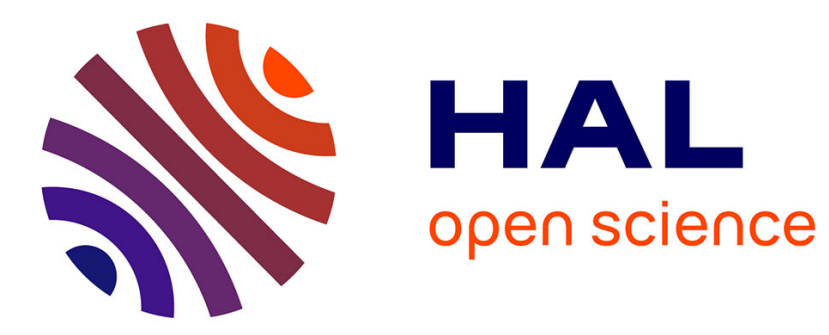

\title{
Contributions to the first Session: the Arabian Peninsula
}

Laila Nehmé, Jean-Pierre van Staevel

\section{To cite this version:}

Laïla Nehmé, Jean-Pierre van Staevel. Contributions to the first Session: the Arabian Peninsula. Semitica et Classica, 2021, pp.173-175. 10.1484/J.SEC.5.122986 . hal-03064031

\section{HAL Id: hal-03064031 \\ https://hal.science/hal-03064031}

Submitted on 14 Dec 2020

HAL is a multi-disciplinary open access archive for the deposit and dissemination of scientific research documents, whether they are published or not. The documents may come from teaching and research institutions in France or abroad, or from public or private research centers.
L'archive ouverte pluridisciplinaire HAL, est destinée au dépôt et à la diffusion de documents scientifiques de niveau recherche, publiés ou non, émanant des établissements d'enseignement et de recherche français ou étrangers, des laboratoires publics ou privés. 
Tribes and tribal spaces in the ancient and medieval worlds. A thematic dossier prepared by Laïla Nehmé and Jean-Pierre Van Staevel.

\section{Introduction}

This introduction and the following four articles are the first contribution, to Semitica and Classica, of an interdisciplinary project which started in 2019 under the aegis of the research laboratory "Orient et Méditerranée" (UMR 8167, Paris). It is placed under the direction of Laïla Nehmé (CNRS) and Jean-Pierre Van Staevel (Université Paris 1 Panthéon-Sorbonne) who are members, in this laboratory, of the "Semitic Worlds" and "Medieval Islam" teams respectively. This project arose from informal discussions we had about the social entities named "tribes" and more specifically about the way these use, occupy, control, own, exploit, and move in, the spaces in which they are found in both ancient and medieval times and in both the Middle East and North Africa. It appeared to us that this spatial perspective had not been fully addressed yet and needed futher investigation from scholars coming from various disciplines and research fields.

As a borrowing from the lexicon of the political institutions of the ancient world, the term "tribe" is biased because it stems from the evolutionist theories. It was used, at first, to account for what was then seen as one of the initial stages of the political organisation of societies. It is still widely used today, in a variety of meanings, to refer to forms of social and political organisation based on real or fictitious kinship ties, the legitimacy of which comes from belonging to a common ancestry. We will of course avoid, here, the frequent confusion, including among academics, between tribes and nomadism. The term "tribe" also applies to societies which, in the absence of a centralised authority, maintain social and political order in a variety of ways. "Tribalism" is thus often used, with a pejorative connotation, to describe collective behaviours that are in conflict with the formation of states. The limits of this understanding are well illustrated by the numerous examples, encountered throughout history, of tribes generating political entities and leading to the construction of states. The dialectic between tribe and State, the shift from one to the other of these political groups, the exercise of sovereignty, are important issues of our work.

The perspective we have chosen to focus on, in this project, is however neither the political nor the social one. The idea we had in mind when we first initiated it was to envisage the tribe, in several geographical and historical contexts, from a perspective that seemed to come from our archaeological background: the spatial perspective. Our aim is not to reflect upon a definition of the word "tribe" but to examine the relation groups identified as such have with space. In other words, we would like to bring the spatial dimension into the historical reflection about the tribe, keeping also in mind the role of social and political factors in this relation. This perspective is applied mainly to the period between between Antiquity and the Middle Ages but does not dismiss modern or contemporary examples.

The issues we are interested in concern both the conceptions of space-in particular the words used to describe it - and the various ways it is actually used by tribes. Tribal spaces are not restricted to geographical entities such as plains, mountains and pastures which are exploited for agriculture or husbandry. Other kinds of spaces, at various scales, can be taken into consideration: town, neighbourhood, sacred places, road network, caravan tracks, access to natural resources, etc.

At the domestic level, tribal identity can be expressed through spaces devoted to social interaction, hospitality and representation. At the village or sanctuary level, it is expressed 
through spaces where sacrifices and banquets are organised periodically to renew social bonds. Finally, at a macrostructural level, one might question the mechanisms of expansion of some tribal groups, the construction of states or empires, and finally the contraction of the sometimes immense spaces controlled by them.

The "Tribes and tribal spaces" project intends to explore these questions as well as those that will emerge during the discussions. It will allow to compare the ideas and experience of colleagues studying societies who lived at various periods in the Middle East and North Africa, and beyond these regions if necessary. The first two sessions of the project have a geographical unity, the Arabian Peninsula in 2019 and North Africa in $2021^{1}$ but this geographical perspective will not be maintained during the following sessions. It was chosen to provide, thanks to the contributions of leading specialists in the field, a general overview which may guide our reflection and lead to more specific topics.

\section{Presentation of the papers}

The first session of the project focused on the Arabian Peninsula from a diachronic perspective. It took place on June 7th, 2019, in the premises of the laboratory "Orient \& Méditerranée" at Ivry-sur-Seine (Paris). The four contributions were sent in advance by their authors and disseminated within the research group before the meeting. During the session itself, each paper was presented briefly by its author before being commented on by an appointed discussant who paved the way for extensive exchanges.

The paper presented by William and Fidelity Lancaster deals with the perception and use of space by Arab tribes, as captured by anthropology in the various regions where the authors undertook studies during their career (Jordan, Oman, United Arab Emirates, Bilād ash-Shām). Socio-economic structures and the fact that accessible resources do not all have the same potential, are complementary to each other, and subject to a very high degree of randomness, imply flexible rules of property and use. Both authors revisit the notion of tribal territory, which they consider less relevant and less appropriate, because it implies the existence of centralised corporate bodies, than the more neutral notion of tribal landscapes and lands. According to the authors' own words, "spaces are defined by people, individuals not corporate bodies, who construct landscapes from observation, use, and experience in geographic spaces". Beyond the issue of access to resources, the article also addresses other dimensions of space, especially those of circulation (in both the spatial and social dimensions) of products and informations. It also makes a useful inventory of the words used by tribes or sections of tribes to name the places where they live according to the social, religious, and legal equipment they have and the kind of activity they practice. Words such as dirah, farij, qaryah, bilād, wațan, manāzil, dār, etc. are among those which recur most often.

Michael C.A. Macdonald's contribution focuses on the data contained in the Safaitic inscriptions, a corpus dated to between the 1st century BC and the 4th century AD. These inscriptions are found in the basaltic region known as the harrah, a desert of broken-up lavaflows in southern Syria, north-eastern Jordan and northern Arabia which was thus frequented by literate nomads in Antiquity. Macdonald gives a description of the various kinds of natural spaces in which the authors of the inscriptions lived. He insists on the permeable character of the social goups, which practiced complementary activities. Groups were not particularly specialised in agriculture, pastoralism, hunting, or gathering, which they combined to ensure

\footnotetext{
${ }^{1}$ The session due to be held in May 2020 was cancelled because of the Coronavirus crisis.
} 
their living. He also examines carefully the way the groups we are interested in called themselves, either through the words ' $h /$ and ' $/$ or through the gentilic adjective, the nisba. Based on the fact that affiliation to these groups is based on geneaology, sometimes drawn back to an eponymous ancestor, he suggests to use the expression "lineage group" instead of the word "tribe" because it is more neutral. Finally, based on a large number of examples taken from the 50000 texts now available ${ }^{2}$ (51 inscriptions are read and translated in the article), he proposes a new pattern of seasonal migrations. One of the main conclusions drawn from the corpus is the remarkable capacity to adapt of the nomadic populations, the mobility patterns of wich vary from year to year according to whether the rains were abundant in one kind of environment or another.

Christian Julien Robin's long contribution proposes a full examination of social groups and their relation with space and territory in both Ancient South Arabia and Arabic medieval sources. He therefore deliberately adopts a wide geographical and long-term chronological perspective and he offers the most complete and most up to date state of knowledge on the way social groups are named in the sources and the territories in which they were present or which they controlled. Besides, through a careful attention given to onomastics, again from a long-term perspective, Robin's paper provides an important update on the changes that affected the memory of groups during the medieval period, when the Arab-Muslim scholarly tradition (and in particular works with a genealogical content) developed as the main source on the subject.

Finally, Peter Webb offers a remarkable contribution on the place names mentioned in preIslamic Arabic poetry, based on the 550 toponyms he identified in a selection of four poetry collections. He gives a summary of the historiographic debate concerning these toponyms, which are considered either as reflecting a spatial reality or as the fruit of the poet's imagination, eager to express himself by metaphor. Based on an accurate study of the topological lexicon, the author's main conclusion is that "most (if not all) places mentioned in poetry were real places [...] but senses of place were evidently not widely shared in pre-Islamic Arabia". This is explained by the fact that "individual poets' spatiality reflected particular, localised lived experiences of distinct spatial worlds". In other words, "spaces as memorised by the poets are expressions of micro-spatiality of different communal milieus": there are no intentions to construct cohesive spatial narratives. Finally, Webb shows that the reception of these poetic materials in Abbasid period anthologies and geographical works consists as much of a mechanism for the constitution of memory as it does for oblivion.

The four contributions which form this thematic dossier reflect their respective author's willingness to draw up a full assessment on the subject in their own field. The material examined either aims at being exhaustive (Macdonald, Robin) or is based on a sample large enough for the conclusions drawn from it to be valid (Lancasters, Webb). Thus, they represent an important contribution to what we know about the perceptions of space in the Arabian Peninsula from Antiquity to the second half of the $20^{\text {th }}$ century. Three of them pay special attention to nomadic societies and to the way they interacted with the space in which they moved. Yet sedentary communities are not absent and mentioned whenever social groups are installed in a territory. A good example is that of the Ancient South Arabian sha' $b$, what Robin calls the "commune", which are "the populations of a territory, not the descendants of a real or fictional ancestor".

\footnotetext{
${ }^{2}$ The previous study on the subject was based on 12000 inscriptions.
} 
All contributions pay a particular attention to toponymy, to the shared knowledge of space and the way it is passed on, modified, forgotten. They also show how unstable the concept of tribe is from one place to another and from one period of time to another, and the difficulty to describe what a tribe is at a particular time and in a particular place. This is even more true when one considers the fact that the written sources which are available to us are not equally reliable because of various processes of transmission. In this respect, the issue concerning the way the memory of tribal space is transmitted and received in the Abbasid period, addressed by two of the papers, is fundamental for our understanding of the biases of our sources. 